EDYTA WÓJCicKA

ORCID 0000-0003-1799-143X

Uniwersytet Marii Curie-Skłodowskiej

$w$ Lublinie

\title{
PRZESTRZEŃ LITERACKA JAKO NOŚNIK WARTOŚCI W PERSPEKTYWIE EDUKACYJNEJ NA PRZYKŁADZIE POWIEŚCI J.R.R. TOLKIENA HOBBIT, CZYLI TAM I Z POWROTEM
}

\begin{abstract}
Wójcicka Edyta, Przestrzeń literacka jako nośnik wartości w perspektywie edukacyjnej na przykładzie powieści J.R.R. Tolkiena Hobbit, czyli tam i z powrotem [Literary Space as a Carrier of Values in the Educational Perspective - a Case Study of J.R.R. Tolkien's The Hobbit or There and Back Again]. Studia Edukacyjne nr 59, 2020, Poznań 2020, pp. 285-310. Adam Mickiewicz University Press. ISSN 12336688. DOI: $10.14746 /$ se.2020.59.18
\end{abstract}

The article attempts to show the role literary space can play as a carrier of values in the literary and cultural education of students. This problem will be discussed using J. R. R. Tolkien's The Hobbit or There and Back Again fantasy novel as an example. Research on the reception of this book in Poland by contemporary teenagers and my experience with the discussed issues have motivated me to describe a few strategies for dealing with this novel in Polish language education in axiological terms.

Key words: literary space, Polish language education, values, fantasy literature, school

Mapa wdziera się niedostrzegalnie do świata literatury; czytamy ksiażki, powieści, eseje i nie zdajemy sobie sprawy z tego, jak bardzo uzależnione sa od świata kłębiące się między równoleżnikami i potudnikami. Mapa dyktuje przede wszystkim wiersze, znakomicie zastęuje to, co nazywamy czesto natchnieniem, dajmonionem, impulsem ${ }^{1}$.

Andrzej Niewiadomski

Dzieło literackie należy do tych przedmiotów, które sa nośnikami wartości i przez które następuje bezpośredni ich przekaz².

Barbara Myrdzik

\footnotetext{
1 A. Niewiadomski, Mapa. Prolegomena, Brama Grodzka - Teatr NN, Lublin 2012, s. 169.

2 B. Myrdzik, Zrozumieć siebie i świat, Lublin 2006, s. 353.
} 


\section{Wprowadzenie}

Literatura, podobnie jak inne teksty kultury omawiane w szkole, uobecnia całe bogactwo wartości, których nośnikami są różnorodne elementy struktury utworu. Badacze literatury pisząc o nośnikach wartości w tekstach literackich, eksponują szczególnie znaczenie przestrzeni literackiej w procesie kształtowania postaw i osobowości człowieka. Zdaniem dydaktyków, obcowanie z literaturą - zwłaszcza z literaturą popularną w „epoce Internetu" i hegemonii popkultury - uznawane jest za jedną z bardziej wysublimowanych form zaspokajania ludzkich potrzeb ${ }^{3}$, a także jako dobro kumulujące różne wartości ${ }^{4}$.

Temat zasygnalizowany tytułem dotyczy oddziaływania przestrzeni literackiej na postawy czytelnicze i świat wartości młodzieży. Rangę dzieła literackiego, szczególnie w edukacji aksjologicznej ${ }^{5}$, dostrzega Maria Kwiatkowska-Ratajczak, zdaniem której elementy struktury utworu literackiego umożliwiają czytelnikowi rozpoznanie relacji i zależności między wartościami $^{6}$. Jednakże, co podkreślają badacze literatury, kształtowanie postaw wobec wartości to zadanie niełatwe i odpowiedzialne. Ciężar spoczywa bowiem w dużej mierze na szkolnym poloniście. Samo poznanie przez ucznia wartości, uobecnionych różnych tekstach kultury, dostrzeżonych przez niego lub wskazanych mu przez nauczyciela, nie wystarczy, aby wartości znaczące dla ludzkiej egzystencji zostały zaakceptowane i włączone do już istniejącego czy też tworzonego systemu wartości, z którym młody czytelnik zechce się zidentyfikować. Warunkiem koniecznym zrozumienia i zaakceptowania (lub odrzucenia) wartości są emocje ${ }^{7}$ i wewnętrzna motywacja - zachwyt, zainteresowanie, zaskoczenie bądź oburzenie.

Oddziaływanie utworu literackiego na czytelnika jest nieprzecenione. Literatura - w przeświadczeniu wielu humanistów i dydaktyków kształcenia

${ }^{3}$ Na ten temat pisze np. E. Kasperski, W świecie potrzeb ludzkich, Przegląd Humanistyczny, 1979, 11-12, s. 53-70.

${ }^{4}$ Zob. J. Misiewicz, Światopogląd i forma. O artystycznych wartościach literatury, Lublin 1983; B. Myrdzik, Zrozumieć siebie i świat.

${ }^{5}$ Edukacja aksjologiczna stanowi podstawę całego programu edukacyjnego człowieka jako procesu trwającego przez całe życie. Jej celem jest przygotowanie wychowanków do świadomego wybierania wartości i określania ich hierarchii jako podstaw konstruowania własnej filozofii $\dot{z} y c i o w e j$, a zatem do odpowiedzialnego podejmowania decyzji i brania także odpowiedzialności za konsekwencje własnych postaw wobec wartości. Zob. K. Olbrycht, Prawda, dobro i piękno w wychowaniu czlowieka jako osoby, Katowice 2002, s. 87-106.

${ }_{6}^{6}$ Zob. M. Kwiatkowska-Ratajczak, Z perspektywy wartości o prozie dla dzieci i młodzieży, Poznań 1994, s. 42.

${ }^{7}$ M. Scheler uważał, że na świadomość aksjologiczną człowieka składają się przede wszystkim akty uczucia wartości - uczucia odkrywają wartości, aby potem usytuować je w całym uniwersum wartości, za: B. Myrdzik, Zrozumieć siebie i świat, s. 144. 
literackiego ${ }^{8}$ - posiada ogromny potencjał poszerzania horyzontów myślowych, wpływa na zwiększanie wrażliwości moralnej, ułatwia odkrywanie i doświadczanie wartości, jest także źródłem mądrości ${ }^{9}$, co zostało już wstępnie zasygnalizowane. To eksplikuje obecność tekstów literackich w procesie realizacji zadań edukacyjnych, a kluczową rolę w organizowaniu sytuacji lekturowych przyznaje się szkolnemu poloniście, jego kompetencjom, wrażliwości i kulturze pedagogicznej ${ }^{10}$. $Z$ uwagi na interesujący problem przedmiotem wiodących oddziaływań nauczycieli powinno być kształcenie kompetencji aksjologicznej ${ }^{11}$, która - będąc podstawowym składnikiem kompetencji poznawczej i kulturowej - wiąże się z rozpoznawaniem przez uczniów wartości, ich rozumieniem, hierarchizowaniem, uwewnętrznianiem i realizowaniem wartości uobecnionych w przestrzeni dzieł literackich.

\section{Przestrzeń w dziele literackim}

Zawarty w tytule termin przestrzeń nie jest pojęciem jednoznacznym, jednolitym. Problematykę przestrzeni można rozpatrywać $\mathrm{w}$ różnych aspektach. $Z$ jednej strony przestrzeń wydaje się czymś prostym i zrozumiałym, z drugiej - skomplikowanym i trudnym do wyjaśnienia. Według Yi-Fu Tuana, prekursora geografii humanistycznej, „przestrzen to abstrakcyjny termin określający złożony zespół pojęć" ${ }^{\prime \prime 2}$. Zdaniem amerykańskiego uczonego, „przestrzeń" określa powszechne doświadczenie, jest - obok „miejsca” - zasadniczym składnikiem naszego świata; uważamy ją za oczywistośćp ${ }^{13}$. Na co dzień żyjemy bowiem $\mathrm{w}$ przestrzeni, mamy do czynienia z rzeczami, które są usytuowane $\mathrm{w}$ rozmaitych odległościach od nas, uformowane w określony sposób, obdarzone konkretnymi (przestrzennymi) własnościami. W powszechnym doświadczeniu przestrzeń, jak zauważa Yi-Fu Tuan, utożsamiana jest z wolnością, natomiast bezpieczeństwo identyfikowane z miejscem. Znaczenie przestrzeni nakłada się często na znaczenie miejsca.

${ }^{8}$ Szczególną rolę w procesie wychowawczym przypisuje literaturze Stefan Sawicki. Zdaniem badacza, wychowawczym powinnościom literatury towarzyszy współcześnie przekonanie, iż literatura, dzięki wartościom estetycznym, istnieje jako wartość „dla”; zob. S. Sawicki, Problematyka aksjologiczna w badaniach literackich, [w:] Problematyka aksjologiczna w nauce o literaturze. Studia, red. S. Sawicki, A. Tyszczyk, Lublin 1992, s. 95-109.

${ }^{9}$ Zob. Przestrzenie rzeczywiste i wyobrażone. Metodyczny wielogłos o różnych przestrzeniach, red. B. Myrdzik, I. Morawska, M. Latoch-Zielińska, Lublin 2016, s. 441.

${ }^{10}$ Zob. B. Myrdzik, Nauczyciel jako organizator dialogu ucznia z tradycja, [w:] Nowoczesność i tradycja w kształceniu literackim. Podręcznik do ćwiczeń z metodyki języka polskiego, red. B. Myrdzik, Lublin 2000, s. 175-187.

${ }_{11}$ Zob. np. E. Ogrodzka-Mazur, Kompetencja aksjologiczna dzieci w młodszym wieku szkolnym, Katowice 2007.

12 Zob. Yi-Fu Tuan, Przestrzeń i miejsce, przekł. A. Morawińska, Warszawa 1987, s. 51.

13 Tamże, s. 13. 
To, co na początku jest przestrzenią, staje się miejscem $\mathrm{w}$ miarę poznawania i nadawania wartości. (...) Dla definicji pojęcia "przestrzeń” i „miejsce” potrzebują siebie nawzajem. Bezpieczeństwo i stabilność miejsca zwraca naszą uwagę na otwartość, wielkość i grozę przestrzeni - i na odwrót. Co więcej, kojarząc przestrzeń z ruchem, odczuwamy miejsce jako pauzę: każde zatrzymanie w ruchu umożliwia przekształcenie sytuacji (położenia) w miejsce ${ }^{14}$.

Tuan zauważył, że ludzie w różnych kulturach różnie organizują sobie przestrzeń, różnie ją dzielą, wartościują i różnie ją mierzą. Przestrzeń jest, w odróżnieniu od miejsca, bardziej bezosobowa, raczej publiczna, dostępna dla każdego, kto ma powody, aby się do niej dostać lub w niej przebywać.

Mimo dostrzegalnych różnic, między przestrzenią a miejscem istnieją znaczące podobieństwa, które wynikają z faktu, że "człowiek jest miarą wszystkich rzeczy". Inaczej - miejsce jest uczłowieczoną przestrzenią. Przestrzeń przekształca się $\mathrm{w}$ miejsce za sprawą nadawanych mu indywidualnych znaczeń i określeń ${ }^{15}$. Oznacza to, iż szukając podstawowych zasad organizacji przestrzennej, przekonujemy się, że to człowiek, struktura jego ciała oraz relacje (bliskie czy dalekie) między istotami ludzkimi organizują przestrzeń. Każdy człowiek jest centrum własnego świata, a otaczająca przestrzeń jest zróżnicowana zgodnie ze schematem jego ciała, z tym jak się porusza. Koordynaty ludzkiego ciała przenoszą się na przestrzeń. Człowiek wyprostowany gotowy jest do działania. Przestrzeń otwiera się przed nim i natychmiast ulega zróżnicowaniu według osi tył - przód, góra - dól, prawa - lewa strona.

Z intymnego doświadczenia własnego ciała oraz innych ludzi człowiek organizuje przestrzeń w ten sposób, by odpowiadała jego biologicznym potrzebom i społecznym stosunkom. Dystans w przestrzeni może być obrazem emocjonalnej i społecznej odległości. Wszyscy ludzie pojmują przecież rozróżnianie między "my" i „oni” oraz że my jesteśmy „tutaj”, a oni są „tam”"16. Odległość oznacza stopień dostępności i zainteresowania. Stąd, jednych odbieramy jako bliskich, innych jako dalekich, mimo iż często nie potrafimy zracjonalizować swojego stosunku do nich. Nie potrafimy także określić przyczyny powstałej granicy między przestrzenią intymną a nieintymną (geograficzną).

Przestrzeń możemy opisać, co dowodzi, że ma formę logiczną, ale nie ma zarazem kształtu - brak jej konkretnej realności czasoprzestrzennej ${ }^{17}$. To ambiwalentne nacechowanie przestrzeni $\mathrm{w}$ realnym świecie pozwala traktować przestrzeń jako potencję, w ramach której zachodzą wszelkie relacje pomię-

${ }^{14}$ Tamże, s. 16.

${ }^{15}$ Zob. Intymne doświadczenie miejsca, [w:] Yi-Fu Tuan, Przestrzeń i miejsce, s. 173-188.

16 Tamże, s. 68.

${ }^{17}$ Na temat bezczasowości przestrzeni zob. więcej: Yi-Fu Tuan, Czas w przestrzeni doświadczalnej, [w:] Yi-Fu Tuan, Przestrzeń i miejsce, s. 152-172. 
dzy obiektami, zbiorami czy też zjawiskami ${ }^{18}$. Co istotne, tak intuicyjnie odczuwana przestrzeń realna staje się harmonijnie zorganizowaną przestrzenią dzieła literackiego, która jakkolwiek pozostaje w relacji do przestrzeni pozatekstowej, nie ma jednak charakteru wiernego odwzorowania. Jest wyabstrahowana $\mathrm{z}$ doświadczenia codziennego, niejako wirtualna ${ }^{19}$. Ta cecha przestrzeni literackiej pozwala kreować fikcyjny świat, w którym zostają osadzeni bohaterowie przeżywający fabularne perypetie.

W rozważaniach teoretycznoliterackich ${ }^{20}$ zwykło się traktować przestrzeń jako jeden z podstawowych elementów struktury działa i kompozycji utworu literackiego. Przestrzeń wyznacza istotę świata przedstawionego i procesów w nim zachodzących. Jest to również byt niesamodzielny, zazwyczaj rozpatrywany w kontekście temporalnym. W każdym bowiem utworze literackim postacie, zdarzenia, czy sytuacje tworzą zarówno określone związki z innymi elementami fabuły, jak i są umiejscowione w jakiejś przestrzeni i czasie. Stanowisko takie reprezentują także autorzy Zarysu teorii literatury, według których świat przedstawiony dzieła literackiego podlega uporządkowaniu zarówno w zakresie organizacji przestrzennej, jak i czasowej. Jednocześnie uporządkowanie to odgrywa zazwyczaj podrzędną rolę wśród czynników kompozycyjnych dzieła literackiego. Jedynie wówczas, kiedy tematem dzieła są układy przestrzenne ${ }^{21}$, stają się one nie tylko scenerią akcji, lecz - przede wszystkim - dominantą kompozycyjną22.

W rozważaniach na temat przestrzeni literackiej możemy mówić o różnych jej kreacjach: przestrzeni sacrum i profanum, przestrzeni bliskiej, w której możliwe jest zadomowienie, i obcej, przestrzeni jako wytworzony i zapamiętany obraz miejsca, przestrzeni autobiograficznej ${ }^{23}$ i tak dalej. Zawsze jednak przestrzeń stanowi motyw bardzo istotny w literaturze. Wielu badaczy zagadnienia uznaje za istotne dla dwudziestowiecznej prozy szczególnie

18 Zob. M. Dereniowska, Wokót przestrzeni natury: substytuty kulturowe jako narzędzie tworzenia przestrzeni życiowej człowieka, Inter Linie. Interdyscyplinarne Czasopismo Internetowe, 2011, 1, s. 36, http://dspace.uni.lodz.pl:8080/xmlui/bitstream/handle/11089/6100/12-mazurkiewicz.pdf?sequence=1, [dostęp: 22.06.2017].

19 Zob. A. Mazurkiewicz, Przestrzeń jako obraz świadomości w powieści Stanistawa Lema „Pamiętnik znaleziony w wannie", Acta Universitatis Lodziensis. Folia Litteraria Polonica, 2013, 4(22), s. 173.

20 Zob. np. M. Bachtin, Formy czasu i przestrzeni w powieści, [w:] M. Bachtin, Problemy literatury i estetyki, Warszawa 1982; M. Głowiński, hasło: Przestrzeń w dziele literackim, [w:] Słownik terminów literackich, red. J. Sławiński, Wrocław 2010, s. 449; M. Głowiński, Przestrzenne tematy i wariacje, [w:] Przestrzeń i literatura, red. M. Głowiński, A. Okopień-Sławińska, Wrocław 1978; A. Kulawik, Poetyka. Wstęp do teorii dzieła literackiego, Warszawa 1990; H. Markiewicz, Czas i przestrzeń w dziele literackim.

$21 \mathrm{O}$ „układach przestrzennych” pisze m.in. M. Porębski, O wielości przestrzeni, s. 25 i n.

22 Zob. M. Głowiński, A. Okopień-Sławińska, J. Sławiński, Zarys teorii literatury, s. 241.

${ }^{23}$ Zob. M. Czermińska, Miejsca autobiograficzne. Propozycja w ramach geopoetyki, Teksty Drugie, 2011, 5(131). 
cztery kategorie przestrzeni, a w zasadzie jej opozycje: przestrzeń rzeczywista - nierzeczywista, przestrzeń otwarta - zamknięta, przestrzeń miasta i przyrody oraz kategoria podróży jako drogi poznania zarówno dalekich terenów, jak i siebie.

Kategoria przestrzeni w literaturoznawstwie ${ }^{24} \mathrm{i}$ jej związków z edukacją polonistyczną ${ }^{25}$ doczekała się wielu znaczących prac, przedstawiających interesujące mnie zagadnienie $\mathrm{z}$ odmiennych perspektyw badawczych ${ }^{26}$. Przestrzeń $w$ dziele literackim to również termin o bliżej niesprecyzowanym zakresie znaczeniowym, odnoszącym się zarówno do treści, jak i struktury utworu. Zróżnicowany charakter omawianej kategorii dostrzega Adam Kulawik. Dla badacza przestrzeń stanowi układ odniesienia opisywanych zdarzeń i postaci, pojawia się jako składnik świata przedstawionego. Pełni też istotne funkcje semantyczne i symboliczne ${ }^{27}$. W koncepcji Janusza Sławińskiego, w utworze literackim możemy mieć do czynienia z przestrzeniami realistycznymi, fantastycznymi, alegorycznymi, groteskowymi, wizyjnymi i śnionymi ${ }^{28}$. Z kolei Henryk Markiewicz w swoich rozważaniach postrzega przestrzeń jako

${ }^{24}$ Szerokim opracowaniem problematyki spacjalnej w literaturoznawstwie jest książka E. Rybickiej, Geopoetyka. Przestrzeń i miejsce we wspótczesnych teoriach i praktykach literackich, Kraków 2014.

${ }^{25}$ Jako cezurę czasową, która określałaby w Polsce początek badań nad kategorią przestrzeni, można przyjąć rok 1977, kiedy w Warszawie 21-23 marca Pracownia Poetyki Historycznej Instytutu Badań Literackich zorganizowała konferencję poświęconą temu zagadnieniu. Efektem spotkania jest książka Przestrzeń i literatura. Tom poświęcony VIII kongresowi slawistów, red. M. Głowiński, A. Okopień-Sławińska, Ossolineum, Wrocław 1978.

${ }^{26}$ Jedną z pierwszych klasyfikacji omawianej kategorii przeprowadził Janusz Sławiński, który wyróżnił siedem perspektyw badawczych dominujących w dociekaniach na temat przestrzeni w dziele literackim: 1. Przestrzeń w poetyce semantycznej ujmowana jest jako jedna z zasad organizacji planu kompozycyjno-tematycznego (rzeczywistości przedstawionej). 2. W poetyce historycznej rozważania dotyczą utrwalonych w tradycji schematów kompozycyjnych przestrzeni przedstawionej, ujęć konwencjonalnych właściwych epokom, kulturom literackim, prądom czy gatunkom. 3. Terenem dociekań semantycznych są wykrywane w systemie znaczeniowym języka wyobrażenia przestrzenne oraz nadbudowane zindywidualizowane systemy znaczeniowo-stylistyczne, w których pierwotne wyobrażenia ulegają reinterpretacji i aktualizacji. 4. Badania kulturowych wzorców doświadczania przestrzeni, w tym przestrzennych relacji między sacrum i profanum, prowadzą do ustalenia roli przedstawień przestrzennych w modelowaniu świata przedstawionego, m.in. obszarów „własnych" i „cudzych", powszechnych i sakralnych, miejsc, stref, stron świata. 5. Badania archetypicznych uniwersaliów przestrzennych wiążą się z problemami stylistyki, poetyki historycznej, kulturologii, najczęściej stanowiąc fundament wyspecjalizowanych badań. 6. Rozważania o charakterze filozoficzno-spekulatywnym przestrzeni literackiej traktują ją jako odwzorowanie przestrzeni fizycznej. 7. Badania nad przestrzennym uformowaniem dzieła literackiego, których terenem są dociekania dotyczące morfologii utworu, układu fabuły, przestrzeni samego przekazu. J. Sławiński, Przestrzeń w literaturze: elementarne rozróżnienia i wstępne oczywistości, [w:] Przestrzeń i literatura, s. 11-14.

${ }^{27}$ Zob. A. Kulawik, Poetyka. Wstęp do teorii dzieła literackiego, s. 257-258.

${ }^{28}$ Zob. J. Sławiński, Przestrzeń w literaturze: elementarne rozróżnienia i wstępne oczywistości, s. 15. 
aspekt zawartości dzieła narracyjnego oraz element konstruujący jego formę, podporządkowany kategorii czasu ${ }^{29}$. Przestrzeń definiuje jako

terytorium, na którym rozwijają się zdarzenia, różne wycinki tego terytorium (np. krajobrazy, wnętrza), wreszcie przedmioty naturalne i wytworzone oraz zjawiska przyrody o ruchu jednostajnym i zmienności powolnej ${ }^{30}$.

W badaniach nad przestrzenią literacką ważne miejsce zajmuje koncepcja chronotopu Michaiła Bachtina. Zgodnie z nią, przestrzeń przedstawiona $\mathrm{w}$ dziele literackim jest ściśle związana z czasem, czego potwierdzeniem jest stosowane przez Bachtina pojęcie czasoprzestrzeni, zwane chronotopem, rozumiane jako „istotne wzajemne powiązanie stosunków czasowych i przestrzennych przyswojonych artystycznie" ${ }^{\prime 31}$. Zgodnie z bardziej szczegółowym opisem:

Czasoprzestrzeń w literaturze artystycznej jednoczy cechy przestrzenne i czasowe w ramach znaczącej i konkretnej przestrzeni. Czas nabiera tutaj gęstości, nieprzejrzystości, staje się czymś artystycznie widzialnym; przestrzeń wciągnięta w ruch czasu, fabuły, historii nasyca się ich energią. cechy czasu odsłaniają się w przestrzeni, zaś przestrzeń znajduje w czasie swój sens i miarę. To krzyżowanie się porząaków i złączenie cech stanowi o charakterze czasoprzestrzeni artystycznej ${ }^{32}$.

Przegląd wybranych stanowisk badawczych i postaw metodologicznych dowodzą wieloznaczności pojęcia przestrzeni literackiej. Z uwagi na przedmiot rozważań, w niniejszej pracy chciałabym zająć się w szczególności rolą przestrzeni literackiej w edukacji kulturowo-literackiej i wykazać, iż przestrzeń utworu może być nośnikiem wartości w procesie kształcenia umiejętności lekturowych uczniów.

\section{Przestrzeń edukacyjna}

Intensywność zmian w zglobalizowanym świecie warunkuje nową rzeczywistość społeczną, a także odnosi się do wymagań edukacji, która nie może ograniczać się jedynie do przekazu pojęć, ale musi obejmować wielostronny rozwój osobowościowy ucznia. Dlatego, w centrum zainteresowania zarówno szkoły, jak i rodzica oraz ucznia znajduje się przestrzeń edukacyjna. Samo pojęcie nie ma jednak precyzyjnego określenia. Odnosić się może do każdego aspektu, w którym zachodzi proces edukacyjny.

\footnotetext{
${ }^{29}$ Zob. H. Markiewicz, Czas i przestrzeń w utworach narracyjnych, s. 134 i n.

${ }^{30}$ Tamże, s. 134.

${ }^{31}$ M. Bachtin, Formy czasu i przestrzeni w powieści, s. 278.

32 Tamże.
} 
Ważny wkład w badania nad związkiem przestrzeni z edukacją, szczególnie polonistyczną, wnosi Barbara Myrdzik ${ }^{33}$. Lubelska badaczka dostrzega transdyscyplinarność pojęcia, które sytuuje się na pograniczu różnych dyscyplin naukowych. Termin przestrzeń edukacyjna stosowany jest przecież współcześnie w różnorodnych publikacjach z dziedziny pedagogiki, politologii, filozofii, czy socjologii. Myrdzik trafnie zauważa, iż przestrzeń edukacyjna

bezpośrednio wiąże się z filozofią przestrzeni, nowym ujęciem regionalizmu, pedagogiką miejsca, aksjologią przestrzeni, socjologią, psychologią oraz dyscyplinami szczegółowymi, jak: literaturoznawstwo (geopoetyka), językoznawstwo (przestrzeń języka), medioznawstwo i innymi dziedzinami ${ }^{34}$.

Cytowana badaczka zwraca uwagę, iż w szerokim znaczeniu przestrzeń edukacyjna to miejsce dokonywania się w nich procesów edukacyjnych, które należy rozumieć jako ciąg systematycznych działań dydaktycznych ${ }^{35}$. Takie wielowymiarowe pojmowanie przestrzeni dostrzegają także inni badacze problemu, zwracając uwagę na konieczność uwzględniania kontekstu społecznego $^{36}$ i topograficznego ${ }^{37}$. To ostatnie odniesienie wiąże się z fizyczną przestrzenią edukacyjną, na którą składa się szeroko pojęta architektura szkoły - budynek, sale lekcyjne, biblioteka, korytarze, boisko, czy szkolny ogród. Ale topografię przestrzeni edukacyjnej tworzą też miejsca "prywatne", tym samym bliskie uczniom, bo przez nich samych odkrywane, bez szkolnych przymusów i stresów. W takim kontekście przestrzenie edukacyjne tworzą dwie wiodące perspektywy: indywidualną i społeczną.

Z punktu widzenia edukacji szkolnej ważniejsza wydaje się perspektywa indywidualna, gdyż - będąc przestrzenią doświadczenia ${ }^{38}$ - uczy refleksyjności i wrażliwości, rozwija wyobraźnię, pozwala kształtować tożsamość ucznia

${ }^{33}$ Zob. B. Myrdzik, Co ma wspólnego przestrzeń z edukacja polonistyczną?, [w:] Przestrzenie rzeczywiste i wyobrażone. Metodyczny wielogłos o różnych przestrzeniach, red. M. Latoch-Zielińska, I. Morawska, B. Myrdzik, Lublin 2016, s. 15-70.

${ }^{34}$ Tamże, s. 60.

${ }^{35}$ Szerzej na temat procesów dydaktycznych pisze W. Okoń, Wprowadzenie do dydaktyki ogólnej, Warszawa 2003, s. 129 i n.

${ }^{36}$ Zob. Przestrzeń edukacyjna wobec wyzwań i oczekiwań społecznych, red. I. Surina, Kraków 2012, s. 15.

${ }^{37} \mathrm{Na}$ temat znaczenia topografii $\mathrm{w}$ tworzeniu przyjaznej uczniowi przestrzeni edukacyjne zob. np. S. Dylak, Architektura wiedzy w szkole, Warszawa 2013; A. Nalaskowski, Przestrzenie i miejsca szkoty, Kraków 2002; C. Szpytma, Rola architektury w tworzeniu aktywnego środowiska edukacji, Teraźniejszość - Człowiek - Edukacja, 2016, 19, 1(73); J. Włodarczyk, Architektura szkoły, Warszawa 1992; I. Zawada, Przestrzeń edukacyjna klasy szkolnej, Roczniki Pedagogiczne, 2013, 5, 2.

${ }^{38} \mathrm{O}$ roli doświadczenia jako formy aktywności człowieka i nośnika wartości uobecnionych w tekstach kultury zob. np.: Doświadczenie lektury. Między krytyką literacką a dydaktyką literatury, red. A. Janus-Sitarz, Kraków 2012; B. Myrdzik, Zrozumieć siebie i świat; Wptyw doświadczenia na proces lektury czytelnika. Refleksje dydaktyczne, [w:] Przestrzenie rzeczywiste i wyobrażone. 
poprzez uczenie się bycia sobą "tu i teraz" oraz w przyszłości. Na tę własną przestrzeń edukacyjną składają się zarówno fizyczne obiekty przestrzenne, jak i płaszczyzna mentalna, którą stanowią wiedza, umiejętności, świat wartości, postawy i przekonania, czy kompetencje kulturowe. Co ważne, przestrzeń osobista nie musi ograniczać się jedynie do szkoły i klasy lekcyjnej, gdyż najpierw tworzy ją dom rodzinny, później przedszkole, szkoła i tak dalej. Indywidualną przestrzeń edukacyjną można również odnaleźć w innym miejscu, na przykład na strychu, w parku, kinie, teatrze, muzeum, a także w książce.

\section{Przestrzeń w literaturze fantastycznej jako nośnik wartości}

W rozważaniach o aspektach przestrzeni edukacyjnej nie można pominąć odniesień aksjologicznych. Szczególnie edukacja polonistyczna, której podstawę stanowią teksty kultury, a wśród nich literackie, nie powinna być prowadzona poza problematyką wartości. Dialog pomiędzy czytelnikiem a utworem literackim odbywa się przecież przede wszystkim za pośrednictwem języka, a ten jako wykładnik werbalizacji przestrzeni, zdaniem Myrdzik, w prymarnym znaczeniu odnosi się do przestrzeni fizycznej i społecznej, tworząc także metafory przestrzenne, wyrażające: myśli, poglądy, idee, przekonania i oceny ${ }^{39}$. Cytowana badaczka uważa, iż literatura - jako sztuka słowa - na poziomie świata przedstawionego tworzy często przestrzeń nie tylko estetyczno-poznawczą, ale i aksjologiczno-poznawczą ${ }^{40}$. Podobne stanowisko zajmuje Stefan Sawicki, który nacechowanie aksjologiczne dzieła literackiego dostrzega "na poziomie świata przedstawionego: przestrzeni, czasu, zdarzeń, postaci" ${ }^{41}$. Przestrzeń literacka może - i powinna być - zatem wykorzystywana jako narzędzie nauczania i wychowania. Szerokie możliwości stwarza przestrzeń w dziełach z gatunku fantastyki. Szczególnie przestrzeń fantasy - jako miejsce działań czarodziejów, dom niezwykłych stworzeń niespotykanych nigdzie indziej i jednocześnie arena walki między dobrem a złem - ma dla utworu ogromne znaczenie. Często uderzająca swoją niezwykłością i odległa czasowo, przestrzennie od znanej nam rzeczywistości lub zorganizowana według innych praw jest nośnikiem głębszych treści i wartości. Utwory fantasy poruszają ponad to istotne dla współczesnego młodego czytelnika problemy i co istotne - są chętnie czytane przez uczniów. Może warto więc przerwać czasem nudę kanonu lektur obowiązkowych, zaryzykować i wygospodarować kilka lekcji na omówienie utworów Johna

\footnotetext{
39 Tamże, s. 66.

40 Tamże, s. 67.

41 S. Sawicki, Problematyka aksjologiczna w badaniach literackich, s. 99.
} 
R.R. Tolkiena, Andrzeja Sapkowskiego, czy Ursuli K. Le Guin. Może sprawi to, iż uczniowie inaczej spojrzą na listę lektur, która nie będzie już dla nich jedynie „zbiorowym obowiązkiem”, ale także rozrywką i inteligentną zabawą, a przy tym „nienachalnym” nośnikiem wartości. Jako doświadczony szkolny polonista wiem, że mądre i celowe organizowanie sytuacji sprzyjających przeżywaniu wartości i wyrażaniu stanów emocjonalnych z nimi związanych decyduje o powodzeniu edukacji aksjologicznej.

Jakie zatem miejsce zajmuje lektura z gatunku fantastyki w szkolnej edukacji literacko-kulturowej?

Analiza obowiązujących dokumentów, regulujących pracę szkolnego polonisty ${ }^{42}$, a także obserwacja własna, dają podstawę do postawienia tezy, iż literatura fantastyczna pojawia się na lekcjach języka polskiego okazjonalnie. I zazwyczaj nie wynika to z braku zainteresowania nią ze strony młodzieży. Przyczyn jest kilka. Przede wszystkim literaturę fantastyczną deprecjonuje większość literaturoznawców. Stanowisko takie podzielają również sami szkolni poloniści, którzy w tej dziedzinie literatury uznają za godne uwagi co najwyżej pisarstwo Stanisława Lema. Inni twórcy tego gatunku są pomijani i uznawani za gorszych niż na przykład Prus, Sienkiewicz, czy Żeromski. Wreszcie dosyć ogólnikowe zapisy w Podstawie programowej ${ }^{43}$ nie zachęcają nauczyciela do sięgania po ten rodzaj literatury czy do głębszej refleksji. W zakresie analizy i interpretacji tekstów kultury na drugim etapie edukacyjnym (klasy IV-VI szkoły podstawowej) dokument ten zobowiązuje nauczyciela do wprowadzenia na lekcjach języka polskiego pojęcia fikcji artystycznej w opozycji do rzeczywistości oraz kształcenia umiejętności odróżniania realizmu od fantastyki ${ }^{44}$, ale identyfikacja gatunków literackich ograniczona zostaje do poznania z interesującego obszaru jedynie baśni ${ }^{45}$. Wśród proponowanych tekstów kultury odnaleźć można Bajki robotów S. Lema, I część Opowieści z Narnii C.S. Lewisa (Lew, Czarownica i stara szafa), powieść Hobbit, czyli tam i z powrotem J.R.R. Tolkiena, czy $W 80$ dni dookota świata J. Verne' $\mathrm{a}^{46}$. Z kolei, na trzecim etapie edukacyjnym Podstawa przewiduje $\mathrm{w}$ obrębie rozpoznawania odmian gatunkowych literatury popularnej identyfikowanie utworów fantastycznonaukowych i fantasy ${ }^{47}$, a na listę lektur wprowadza „wybrane opowiadanie” S. Lema, S. Mrożka oraz utwory

${ }^{42}$ Mam tu na uwadze przede wszystkim podstawę programową z języka polskiego oraz programy nauczania.

43 Odwołując się do zapisów podstawy programowej, mam na uwadze obowiązujący dokument: Podstawa programowa z komentarzami. Jezyk Polski, t. 2, MEN, Warszawa 2009.

${ }^{44}$ Tamże, s. 30.

45 Tamże, s. 31.

46 Tamże, s. 32-33.

47 Tamże, s. 37. 
U. Le Guin, J.R.R. Tolkiena i A. Sapkowskiego ${ }^{48}$, jednakże bez wskazania tytułów, pozostawiając wybór nauczycielowi, postępującemu najczęściej według sugestii autorów podręczników, którzy umieszczają w nich nie tylko stosowne teksty, także wskazują sposoby ich omawiania ${ }^{49}$. Literatura fantastyczna nie jest też zalecana na kolejnym - czwartym - etapie edukacyjnym. W liceum (bądź technikum) młodzież nie znajdzie na liście lektur tego typu utworów, pojawia się jedynie - na poziomie podstawowym - realizm magiczny, niewymieniony co prawda z nazwy, ale reprezentowany przez utwór G.G. Marqueza Sto lat samotności oraz fantastyka naukowa reprezentowana przez klasyczne dzieło S. Lema - Solaris ${ }^{50}$. W zakresie rozszerzonym wśród tekstów kultury odnajdujemy jedynie reprezentantów interesującego nas gatunku literackiego - O. Tokarczuk i wskazanych już S. Lema oraz G.G. Marqueza.

Obecność - a raczej fragmentaryczność i instrumentalność ujęcia literatury fantastycznej w Podstawie programowej - może tłumaczyć zjawisko marginalizowania fantastyki i redukowania do minimum wiadomości z dziedziny jej poetyki w edukacji polonistycznej. Ta krótka analiza zapisów Podstawy programowej mogłaby potwierdzać tezę o braku zainteresowania fantastyką i uzasadniać podrzędne ujmowanie tego gatunku prozatorskiego w szkolnym kanonie. Dlaczego zatem literatura fantastyczna powinna być obecna w szkolnej edukacji polonistycznej? Powodów wydaje się kilka.

Interesujące $\mathrm{w}$ kontekście omawianego problemu są ustalenia Zbyszko Melosika ${ }^{51}$. Badacz, poświęcając uwagę kulturze popularnej52, zauważa, iż w coraz większym stopniu dominuje ona w życiu codziennym współczesnego społeczeństwa i staje się także jednym z najważniejszych czynników socjalizacji młodego pokolenia. Przy czym, socjalizację rozumie „zarówno jako spontaniczne wrastanie w normy zachowań społecznych, jak i naturalne przyswajanie norm i wzorów kultury symbolicznej" ${ }^{53}$. Zdaniem cytowanego badacza, szkoła, podobnie jak rodzina, uważana za tradycyjną instytucję socjalizacji, traci obecnie na znaczeniu. Natomiast, wzorów zachowań dostarczają rówieśnicy oraz szeroko pojęte obcowanie z kulturą popularną, a nie uczący ich nauczyciele czy kanoniczne teksty literackie, gdyż

48 Tamże, s. 40.

49 Na problem zwraca też uwagę A. Smuszkiewicz, Fantastyka w gimnazjum, [w:] Horyzonty polonistyki. W kręgu edukacji, języka i kultury, red. M. Karwatowska, M. Latoch-Zielińska, I. Morawska, Lublin 2010, s. 143-159.

50 Podstawa programowa z komentarzami, s. 50-51.

51 Zob. Z. Melosik, Kultura popularna jako czynnik socjalizacji, [w:] Pedagogika, red. Z. Kwieciński, B. Śliwerski, Warszawa 2004, s. 68.

52 Kultura popularna rozumiana tu w sensie zainteresowania społecznego.

53 Z. Melosik, Kultura popularna, s. 68. 
to nie treść Lalki Bolesława Prusa czy Trenów Jana Kochanowskiego dyskutowana jest na dużej przerwie, lecz (...) strategie przetrwania zawarte $\mathrm{w}$ ostatniej przebojowej grze komputerowej ${ }^{54}$, komiksie, czy "modnej” książce ${ }^{55}$.

W kontekście ustaleń Melosika należy przyjąć, iż literatura fantastyczna, rozumiana jako część kultury popularnej - co potwierdzają badania zainteresowań czytelniczych prowadzone wśród współczesnej młodzieży ${ }^{56}$ - powinna zajmować stałe miejsce w szkolnej przestrzeni literacko-kulturowej. Tym bardziej że rozbudzanie motywacji i kształcenie preferencji czytelniczych w realiach współczesnej kultury - pozostającej pod silnym wpływem mediów, nowych technologii, alternatywnych stylów życia, zróżnicowanych systemów wartości - okazują się przecież niezwykle trudne. Na problem ten zwraca uwagę także Grzegorz Leszczyński:

Czytanie jest postrzegane przez współczesne (...) społeczeństwo jako forma zachowania nieoczywistego. Oczywiste dla młodego pokolenia jest korzystanie z telefonu komórkowego i Internetu, czytanie jest pewnego rodzaju dziwactwem, na które pozwolić może sobie każdy, ale nie każdy odczuwa tego rodzaju potrzebę. Żeby czytanie nie zostało z horyzontu zachowań społecznych trwale wyrugowane, książka musi w jakiś sposób skusić młodego, nastoletniego czytelnika, czymś go znęcić, zaciekawić, uwieśćc ${ }^{5}$.

Jednakże, liczne sondaże czytelnicze ${ }^{58}$ dowodzą, że zarówno młodzież, jak i dorośli czytają przede wszystkim z obowiązku - zawodowego bądź

54 Tamże.

${ }^{55} \mathrm{Na}$ temat mody czytelniczej piszą m.in. G. Leszczyński: „Książka, jak moda, zmienia się w tempie niespotykanym wcześniej. Jest jednym z wielu strojów kultury współczesnej. By uczestnik tej kultury znalazł w niej ukontentowanie, musi ona, jak każdy strój, dobrze przylega, odpowiadać snobizmom i modom, być funkcjonalna i praktyczna, przede wszystkim - potrzebna", Bunt czytelników. Proza inicjacyjna netgeneracji, Warszawa 2010, s. 128-129; J. Tomkowski: „Nie mogę pojąć namiętności, z jaką większość ludzi czyta nowe książki. (...) Książka nieprzeczytana jest dla mnie pod każdym względem książką nową, niezależnie od tego, czy wydrukowana wczoraj, czy też przed trzystu laty (...). Dla wielu jednak ludzi przeczytanie książki, która nie ukazała się w ostatnim miesiącu lub choćby w ubiegłym roku, jest pomysłem równie dziwacznym jak nałożenie starej broni. Istnieje moda na lekturę podobnie, jak i na stroje, moda nietrwająca dłużej aniżeli jeden sezon", Bestsellery i arcydzieła, [w:] J. Tomkowski, Zamieszkać $w$ Bibliotece, Ossa 2004, s. 51.

${ }^{56}$ Ciekawym ujęciem współczesnego stanu czytelnictwa w kontekście społecznym jest książka L. Stetkiewicz, Kulturowi wszystkożercy sięgaja po książkę. Czytelnictwo ludyczne jako forma uczestnictwa w kulturze, Toruń 2011.

${ }^{57}$ G. Leszczyński, Bunt czytelników. Proza inicjacyjna netgeneracji, s. 129.

${ }^{58}$ Zob. np. A. Has-Tokarz, Czytelnictwo wspótczesnych nastolatków (opinie, obserwacje, badania), [w:] Kultura popularna w szkole. Pobtażliwe przyzwolenie czy autentyczny dialog, red. B. Myrdzik, M. Latoch-Zielińska, Lublin 2006, s. 169-180; L. Stetkiewicz, Kulturowi wszystkożercy sięgaja po ksiażkę, s. 252-340; Raport z badań: Czytelnictwo dzieci i młodzieży, red. Z. Zasacka, Instytut Badań Edukacji, Warszawa 2014, http://eduentuzjasci.pl/images/stories/publikacje/ibe-raport-badanie-czytelnictwo-streszczenie.pdf [dostęp: 3.05.2017]; Raport z badań: Stan czytel- 
szkolnego. Tylko nieliczni sięgają po literaturę klasyczną. Większość wybiera nowości, to co modne, o czym głośno w prasie, telewizji, Internecie, tak zwane bestsellery. $Z$ własnej inicjatywy sięgają przede wszystkim po nową literaturę, szczególnie fantastyczną. Potwierdzają to także wyniki moich badań zrealizowane wśród 120 ankietowanych uczniów ostrowieckich gimnazjalistów w roku $2016^{59}$. Ponad $82 \%$ respondentów przyznało, że lubi czytać książki i jeśli po nie sięga - to dla przyjemności (39\%) lub obowiązku zapoznania się z lekturą szkolną (42\%). Badanie preferencji czytelniczych wykazało, że gimnazjaliści (uczniowie mogli zaznaczyć 3 odpowiedzi spośród 11 możliwości) - poza lekturą szkolną - najchętniej sięgają po książkę młodzieżową (43\%), przygodową (42\%), fantasy (39\%) i kryminał (30\%). Młodzież w czytanych przez siebie utworach szuka przede wszystkim mocnych wrażeń $(45 \%)$ i ciekawych postaci $(40 \%)$.

Ustalenia odnoszące się do zainteresowań czytelniczych młodzieży szkolnej i uwzględnienie uwarunkowań kulturowych pozwalają na kolejne konstatacje. Rzeczywistość, w której żyjemy i w której znajduje się nasz uczeń, zorientowana jest na odwrót od wszelkich idei i kult codzienności. Intensywność zmian, tempo życia, odwracanie się od przeszłości i jednocześnie delektowanie drobiazgami dnia codziennego sprawiają, że szczególnie młody człowiek pozbawiony jest możliwości rozmów na poważne tematy, nie dyskutuje o przyczynach i konsekwencjach własnych postaw czy wyborów. Zanika styl życia oparty na refleksji nad wartościami, sensem życia, a także na odkrywaniu wartości i poszukiwaniu sensu życia ${ }^{60}$. Wobec takiego obrazu współczesności powraca kwestia powinności szkoły i sensu słowa edukacja, w kontekście szkolnym, rozumianego jako nauka, w szerszym - utożsamianym z wychowaniem. Powinnością szkoły (a tym samym nauczyciela) jest przecież nie tylko nauczanie, również wychowanie, stąd mój postulat dostrzegania znaczenia edukacji aksjologicznej w edukacji polonistycznej. Aby jednak to powinność mogła być spełniana, młody człowiek musi otrzymać właściwe wsparcie w poszukiwaniu, odkrywaniu i poznawaniu wartości nadających sens ludzkiemu życiu. Dlatego, podzielam

nictwa w Polsce $w 2015$ roku, Biblioteka Narodowa, http://www.bn.org.pl/download/document/1459845698.pdf [dostęp: 3.05.2017]; Z. Zasacka, Nastolatki i książki - od czytania codziennego do unikania, Edukacja, 2012, 2, s. 20-35.

${ }^{59}$ W pilotażowych badaniach przeprowadzonych w roku szkolnym 2015/2016 w Ostrowcu Świętokrzyskim uczestniczyło 120 gimnazjalistów, 70 rodziców i 40 nauczycieli.

${ }^{60}$ Zob. J. Mariański, Sens życia - wartości - religia, Lublin 2013. Więcej na temat sensu życia w świadomości młodzieży oraz wartości literatury w kształceniu aksjologicznym piszą także: Literatura w kręgu wartości, red. S. Sawicki, Lublin 2009; S. Sawicki, Problematyka aksjologiczna w badaniach literackich; A. Tyszczyk, Interpretacja, sens i wartość, [w:] Wartość i sens. Aksjologiczne aspekty teorii interpretacji, red. S. Sawicki, Lublin 2003; Wartościowanie a edukacja polonistyczna, red. A. Janus-Sitarz, Kraków 2008. 
zdanie badaczy ${ }^{61}$, że mądrze zorganizowana edukacja aksjologiczna pozwala nauczycielowi nie tylko wprowadzić ucznia w świat wartości i pomóc mu je dojrzeć, nazwać, zrozumieć i uwewnętrznić, także zmotywować do uzewnętrznienia. W moim przekonaniu, to właśnie lekcje języka polskiego są ogromną szansą, by wychować ludzi refleksyjnych, którzy świadomie i z uwagą odbierają teksty literackie, bo to między innymi dzięki nim człowiek kształtuje własny światopogląd. Ważną rolę w tym procesie mogą odegrać lektury zarówno z kręgu ścisłego kanonu, ale także spoza listy szkolnych propozycji.

Wpływ nauczyciela na proces kształtowania uczniowskich postaw i odkrywania przez nich wartości uobecnionych w dziełach literackich jest więc nie do przecenienia. Współczesny młody czytelnik odczuwa "opór" wobec książki, przede wszystkim wobec lektury szkolnej, którą uważa za trudną i niezrozumiałą, ze względu między innymi na poetykę, metaforyczność, symbolikę, nietypową konstrukcję, kompozycję czy narrację. Nie oznacza to jednak, że nastolatek nie czyta w ogóle, czego dowodzą przywołane wyniki badań w obszarze czytelnictwa. Czyta, ale przede wszystkim powieści młodzieżowe, łatwiejsze i atrakcyjniejsze w odbiorze. I nie można pominąć tu stanowiska Janusza Sławińskiego, który - pisząc o priorytetach polonistycznej edukacji - eksponuje „rozbudzanie i uszlachetnianie pożądań czytelniczych, przygotowywanie do lektur podejmowanych z własnej potrzeby i ciekawości" 62. Jestem zdania, że proces degradacji książki będzie tym bardziej trudny do powstrzymania, im częściej nauczyciele zamkną się w obowiązkowej ofer$\mathrm{cie}^{63}$. Nauczyciel powinien stwarzać uczniom możliwości zachowania wolności czytelniczej, umiejętnie godzić subiektywne odczucia wobec lektury z przekazywaniem wiedzy nie tylko na temat samej literatury, także wartości wpisanych w literaturę. Samodzielne lektury mają - co zostało zauważone - ogromne znaczenie dla kształtowania świadomego odbioru utworu przez ucznia. To przecież właśnie podczas kontaktu z osobiście wybraną książką czytelnik nawiązuje rzeczywisty dialog z tekstem. Na półkach księgarskich nie ma opracowań tych książek, które młodzi ludzie czytają dla przyjemności. Szczególnie miłośnicy literatury fantastycznej reprezentowanej przez lubianych autorów - J.K. Rowling, J.R.R. Tolkiena, S. Sapkowskiego czy S. Lema z pewnością nawet nie sięgnęliby po streszczenie i nie zadowoliliby się „ścią-

${ }^{61}$ Zob. np. B. Myrdzik, Trudne tematy, trudne rozmowy na lekcjach języka polskiego w gimnazjum, Język Polski w Szkole - gimnazjum, 2000/2001, 2, s. 52-57.

${ }^{62}$ J. Sławiński, Literatura w szkole: dziś i jutro, [w:] Teksty i teksty, red. J. Sławiński, Kraków 2000, s. 68 .

${ }^{63}$ Szerzej na ten temat piszę w artykule: Problemy wspótczesnych nastolatków w powieściach Marty Fox "Iza Anoreczka” i „Iza Buntowniczka”, Język Polski w Liceum. Zeszyty Kieleckie, 2015/2016, 1, s. 86-95. 
gą". Dlatego, mając na uwadze zainteresowania czytelnicze młodzieży, warto postulować, aby literatura fantastyczna była ważną propozycją lekturową na lekcjach języka polskiego w starszych klasach szkoły podstawowej i w gimnazjum.

W tym miejscu należy powrócić do kwestii obecności literatury fantastycznej w szkolnej edukacji kulturowo-literackiej. Warto też sprecyzować cechy interesującego mnie gatunku literackiego.

Autorzy Stownika terminów literackich definiują fantastykę jako:

typ twórczości literackiej w sposób swoisty budujący świat przedstawiony: składają się nań elementy, które nie odpowiadają przyjętym w danej kulturze kryteriom rzeczywistości, a więc wątki nadnaturalne i wszelkiego rodzaju cudowności ${ }^{64}$.

Fantastyka stanowi domenę utworów fabularnych. W ciągu stuleci wytworzyła odrębne gatunki, z których najbardziej reprezentatywna jest baśń, a także szereg odmian gatunkowych, na przykład powieść fantastyczna. Jej odrębną odmianą jest fantastyka grozy (horror). Oryginalną formę fantastyki - fantasy - stworzył w cyklach powieściowych J.R.R. Tolkien, kształtując ją jako swoistą nową mitologię.

Z uwagi na intersujący mnie utwór fantasy - Hobbit, czyli tam i z powrotem J.R.R. Tolkiena - należy też odnieść się do cech gatunkowych tej odmiany literatury fantastycznej. Fantasy to niewątpliwie jedno z najciekawszych zjawisk w literaturze XX i XXI wieku, jednocześnie bardzo trudne do prawidłowego ujęcia. Podstawowym problemem dla ustalenia definicji fantasy jest mnogość zaliczanych do tego gatunku utworów oraz ich różnorodność pod względem walorów literackich, formy, czy stylu ${ }^{65}$. Określenie „literatura fantasy" rozumiane jest nierzadko jako literatura niemimetyczna w ogóle, w której nie obowiązują konwencje realizmu, a występują elementy w potocznej opinii określane jako „fantastyczne”. Przykładem takiego typu definicji jest zamieszczona w Stowniku terminów literackich:

${ }^{64}$ Fantastyka, [w:] Stownik terminów literackich, red. M. Głowiński, T. Kostkiewiczowa, A. Okopień-Sławińska, J. Sławiński, Wrocław 2008, s. 149-150.

${ }^{65}$ Fantasy ma wiele podgatunków, m.in.: heroic fantasy (literatura spod znaku magii i miecza), low fantasy (quasi-historyczna; charakteryzuje się realizmem zbliżonym do świata rzeczywistego, bardzo często nawiązując do istniejących w nim realiów), dark fantasy (podgatunek łączący ze sobą fantasy i horror), high fantasy (akcja rozgrywa się w wymyślonym lub równoległym świecie; bohaterowie nie są typami herosów, lecz zazwyczaj ludźmi zmuszonymi do pewnych odważnych, bohaterskich czynów niejako z przymusu; często to tzw. antybohaterowie), urban fantasy (akcja rozgrywa się $\mathrm{w}$ realiach wielkomiejskich) oraz space fantasy (akcja koncentruje się wokół romantycznych przygód, podróży międzygwiezdnych i kosmicznych bitew). Na podstawie: Fantasy. Ilustrowany przewodnik, red. A. Miszkurka, Warszawa 2003, s. 35-37; Fantasy, [w:] Stownik literatury popularnej, red. T. Żabski, Wrocław 1997, s. 103-104. 
Fantasy (...) - jedna z odmian literatury fantastycznej (...), charakterystyczna dla literatury $X X$ w., mająca jednak antecedencje w literaturze dawniejszej (m.in. Alicja $w$ krainie czarów L. Carolla). F. radykalnie kwestionuje obowiązujące poczucie realności i konwencje realistyczne (...), buduje świat przedstawiony, w którym dominują dziwność i groteska. Operuje bogatą akcją, wypełnioną niezwykłymi wydarzeniami, na ogół logicznie i przejrzyście zbudowaną. F. nawiązuje do różnego rodzaju baśni i mitów, z reguły poddając je przekształceniom ${ }^{66}$.

Ta przytoczona definicja, mimo uogólnień, najczęściej przywoływana jest w szkolnej rzeczywistości. Tymczasem fantasy powinno być raczej rozumiane jako wewnętrznie spójna narracja, która często umieszczona zostaje w innym lub też wtórnym świecie. I chociaż świat ten sam w sobie wydaje się niemożliwy, nierealistyczny, to opowieści w nim umieszczone stają się jednak możliwe za sprawą własnych wewnętrznych reguł.

Termin fantasy wprowadził do polskiej terminologii literaturoznawczej Stanisław Lem, w eseju Fantastyka i futurologia ${ }^{67}$. Warto jednak zauważyć, że pojęcie to nie odnosi się jedynie do słowa pisanego. W szerszym znaczeniu, fantasy obejmuje między innymi komiksy, ilustracje, grafikę, utwory muzyczne, filmy, czy gry komputerowe. Kategoria fantasy bywa też częściej analizowana z perspektywy kulturoznawstwa, psychologii, religioznawstwa, etyki oraz socjologii, niż jako konwencja literacka. Świadomość powstania nowego gatunku literackiego, jakim jest fantasy, pojawiła się wśród krytyków i znawców literatury w połowie lat 60 . Gatunek ten utożsamiany był przede wszystkim z twórczością J.R.R. Tolkiena. W kulturze popularnej fantasy zdominowane jest przez odmianę mediewistyczną, zwłaszcza od czasu ogólnoświatowego sukcesu dzieł J.R.R. Tolkiena, wchodzących w skład mitologii Śródziemia ${ }^{68}$. Na gruncie polskim Hobbita ${ }^{69}$ określano zazwyczaj jako fantastykę baśniową lub niezwykle rozbudowaną baśń, kierowaną również do dorosłej publiczności.

${ }^{66}$ Fantasy, [w:] Stownik terminów literackich, s. 149.

${ }^{67}$ Leksykon polskiej literatury fantastycznonaukowej, red. A. Niewiadomski, A. Smuszkiewicz, Poznań 1990, s. 287-291.

${ }^{68}$ Kontynuacją powieści Hobbit, czyli tam i z powrotem jest Władca Pierścieni (powieść high fantasy mylnie nazywana trylogią, w rzeczywistości - ze względu na swoją dużą objętość - została wydana w trzech tomach: t. 1 - Drużyna Pierścienia, t. 2 - Dwie wieże, t. 3 - Powrót króla). Po raz pierwszy publikowana w latach w latach 1954-1955. Sequel (następstwo w czasie, kontynuacja) oraz prequel (dzieje poprzedzające) to podstawowe kategorie odnoszące się do struktury literatury fantasy, szczególnie heroic fantasy - gatunku reprezentowanego przez dzieła J.R.R. Tolkiena.

${ }^{69}$ Powieść Hobbit czyli tam i z powrotem najpierw ukazała się w Anglii w 1937 roku, w następnym - w USA. Została przełożona na ok. 50 języków. Polski przekład, dokonany przez Marię Skibniewską (po raz pierwszy w roku 1960, kolejne: 1985, 1991, 1995, 1997, 2004, 2007, 2012), był czwartym - po szwedzkim, niemieckim i holenderskim - tłumaczeniem na język europejski. 


\section{Od przestrzeni literackiej do wartości}

Akcja utworów z gatunku fantasy rozgrywa się zawsze w świecie alternatywnym, opartym na realiach cywilizacyjnych zbliżonych do średniowiecznych, i rządzonym nie prawami fizyki, lecz magią. W odróżnieniu jednak od baśni, w fantasy brak obowiązkowego baśniowego morału i schematyzmu fabularnego. Również struktura postaci jest wielowymiarowa i nierzadko pogłębiona psychologicznie ${ }^{70}$. Tym, co naprawdę się liczy i co stanowi o unikatowości utworu fantasy, jest jego tło geograficzno-historyczne. Reprezentatywny dla tego gatunku Hobbit, choć opowiada o fantastycznych wydarzeniach ${ }^{71}$ dziejących się w stworzonym przez autora Śródziemiu w czasach Trzeciej Epoki ${ }^{72}$, porusza aktualne i ponadczasowe problemy, takie jak wartość przyjaźni, solidarność, lojalność, poświęcenie, czy odwieczna walka dobra ze złem.

Przestrzeń i miejsce ${ }^{73}$ wydarzeń rozgrywających się na kartach utworów literackich mają zazwyczaj charakter konkretu - muszą być "gdzieś" umiejscowione. Zdaniem Myrdzik, przestrzeń „jest raczej publiczna, dostępna dla każdego, miejsce zawsze należy do kogoś, a dostęp do niego jest limitowany, symbolicznie lub fizycznie"74. Tak też jest w przypadku Hobbita. Już pierwsze zdanie: „W pewnej norze ziemnej mieszkał sobie pewien hoobit”75 określa nie tylko miejsce jako element przestrzeni, stanowi także wprowadzenie

${ }^{70}$ Zob. Fantasy, [w:] Stownik literatury popularnej, s. 103.

${ }^{71}$ Bohater książki Bilbo Baggins, „istota większa od liliputa, mniejsza jednak od krasnala", zostaje namówiony przez czarodzieja Gandalfa do dalekiej i niebezpiecznej podróży wraz z trzynastoma krasnoludami, by pomóc im w odzyskaniu dawnej krainy, zawłaszczonej - ze skarbami - przez smoka Smauga.

${ }^{72}$ Czas wydarzeń opisywanych w Hobbicie został wyraźnie określony (lata 2941-2942). Właściwa akcja utworu, czyli wędrówka bohaterów, rozgrywa się pomiędzy 29 kwietnia a 22 czerwca roku następnego, czyli trwa ponad rok. Oprócz tego autor stosuje retrospekcje. Mamy także do czynienia z zastosowaniem przedakcji (np. gdy dowiadujemy się o wyganianiu krasnoludów z Samotnej Góry przez smoka Smauga) oraz opisami wydarzeń, które miały miejsce kilka lat po akcji właściwej (wizyta Gandalfa i Balina u Bagginsa). Pisarz nie tylko usytuował w czasie wszystkie wydarzenia, także opisał je w dodatku do trylogii Wtadca Pierścieni. Tam właśnie czytelnik przekonuje się, że krasnoludy przybyły do Hobbitonu w 2941 roku Trzeciej Epoki, w której światu zagroziła straszliwa władza Saurona - władcy ciemności i zła. W tym samym roku Bilbo odnalazł pierścień, który bohaterowi posłużył wyłącznie jako magiczny przedmiot, pozwalający na bycie niewidzialnym, ale naprawdę jego posiadanie dawało nieograniczoną władzę nad wszystkimi żywymi istotami. To właśnie on był tym „Jedynym”, pozwalającym zebrać pozostałe pierścienie potęgi.

${ }^{73} \mathrm{Na}$ temat miejsca jako elementu przestrzeni zob. więcej: H. Buczyńska-Garewicz, Miejsca, strony, okolice. Przyczynek do fenomenologii przestrzeni, Kraków 2006; B. Jałowiecki, M. Szczepański, Miasto i przestrzeń w perspektywie socjologicznej, Warszawa 2002; E. Rybicka, Od poetyki przestrzeni do polityki miejsca. Zwrot topograficzny w badaniach literackich, Teksty Drugie, 2008, 4, s. 21-38; Y-Fu Tuan, Przestrzeń i miejsce.

${ }^{74}$ B. Myrdzik, Co ma wspólnego przestrzeń z edukacja polonistyczna, s. 25.

${ }^{75}$ J.R.R. Tolkien, Hobbit, czyli tam i z powrotem, przekł. M. Skibniewska, Warszawa 1997, s. 5. 
do szczegółowego opisu mieszkania Bilbo Bagginsa, tytułowego bohatera ${ }^{76}$. Dom hobbita - norka w wiosce Bag End pod Pagórkiem - to przestrzeń wewnętrzna, prywatna, dająca mu poczucie intymności. Dom bohatera odgrodzony jest od świata zewnętrznego ścianami podziemnych korytarzy. Przez to staje się miejscem gwarantującym mu bezpieczeństwo, miejscem, którego nie chce opuszczać i do którego ochoczo wraca z rocznej wyprawy spod Samotnej Góry ${ }^{77}$. Jest to także element charakterystyczny dla fantasy - świat przedstawiony jest tu bardzo rozbudowany, składa się wielu elementów, ponieważ autorzy często dążą do stworzenia całościowego obrazu wykreowanej fantastycznej przestrzeni, na którą składają się miejsca, mieszkańcy, historie i prawa nią rządzące. Sprawia to, że w przeciwieństwie do miejsc takich jak dom, gospoda, pałac, które stanowią powierzchnię zamkniętą, przestrzeń w fantasy jest zazwyczaj otwarta, dynamicznie się przetwarza, wiele może się w niej zmienić, także sam bohater ma możliwość dokonać w niej zmian, zaznaczyć swoje istnienie i działanie. Otwarcie przestrzeni - w przeciwieństwie do przestrzeni zamkniętej - daje też szersze możliwości interpretacyjne. Poza tym, w świecie fantasy zauważamy zetknięcie lub przenikanie się przestrze$\mathrm{ni}^{78}$. Przestrzeń, która przechodzi ciągłe metamorfozy, z czasem się odradza, powtarzając wykorzystany schemat. Powrót do punktu wyjściowego ma także związek ze sposobem zbudowania czasu - ponieważ $w$ fantasy czas jest święty, czas mitu łączy się z czasem zwykłymª ${ }^{79}$.

Istotną kwestią dotyczącą literatury fantasy jest waloryzacja przestrzeni. Budowa świata przedstawionego odzwierciedla podział no dobro i zło, a także tendencję człowieka do porządkowania otoczenia według wartościujących kryteriów. Stąd przestrzeń, w której rozgrywają się wydarzenia, ma związek z kierunkami świata oraz ruchem w górę i dól, co może mieć swoje uzasadnienie $\mathrm{w}$ tradycji kultury europejskiej, szczególnie zachodniej. Wędrówka w górę oznacza czystość i szczęście (dobro), droga wiodąca w dół - cierpienie, smutek, nieszczęście (zło). Znacząca jest także symbolika lewej i prawej

${ }^{76}$ Hobbici, nazywani niziołkami, to jedna $\mathrm{z}$ inteligentnych ras stworzonych przez J.R.R. Tolkiena. Cechuje ich niski wzrost i krępa postura.

77 Samotna Góra (inaczej Erebor) jest dawną siedzibą krasnoludów i głównym celem wyprawy bohaterów książki. W dołączonej przez autora na końcu książki mapie widać, iż Samotna Góra położona jest na równinie rozciągającej się na wschód od północnej części Mrocznej Puszczy, w niewielkiej odległości od Długiego Jeziora, stanowiąc charakterystyczny punkt Rhovanionu. Od jej głównego masywu odchodziło sześć długich ramion, a z wnętrza góry wypływała Bystra Rzeka.

${ }^{78}$ Przykładem przenikania się przestrzeni i powrotów do punktu wyjścia jest „znikanie” i „pojawianie się" Bilba za sprawą magicznego pierścienia. Także sam tytuł („tam i z powrotem") sugeruje powrót do punktu wyjścia i stanowi klamrę kompozycyjną wędrówki bohaterów wewnątrz przestrzeni literackiej.

${ }^{79} \mathrm{Na}$ temat czasy w literaturze fantasy pisze A. Rudzka, Czas w fantasy, http://www.fahrenheit.net.pl/archiwum/fif_p1/36.html [dostęp: 23.05.2017]. 
strony, co odnosi się do lewej i prawej ręki. We wszystkich niemal kulturach prawą stronę ceni się wyżej niż lewą. Prawa strona wiąże się ze świętą siłą, zasadą ukierunkowanego działania i źródłem wszystkiego, co dobre i uprawnione. Lewa strona jest antytezą: oznacza świeckie, nieczyste, niepewne, słabe, to, co jest złe i czego należy się bać ${ }^{00}$. Konstrukcja rozmaitych rodzajów przestrzeni $w$ literaturze fantasy przekłada się na strony świata, aczkolwiek nie jest ona zgodna z konceptualizacją przestrzeni stworzoną przez zachodnią kulturę. Przywołany już klasyk teorii przestrzeni zauważa:

W starożytnej Grecji strony wschodnia i zachodnia obdarzone były bogactwem symbolicznych znaczeń. Wschód kojarzył się ze światłem, bielą, niebem, wznoszeniem się; zachód sugerował ciemność, ziemię i opadanie ${ }^{81}$.

Przestrzeń Hobbitonu zamieszkiwanego przez bohaterów pozytywnych usytuowana jest na zachodzie, wschód jest natomiast siedliskiem zła. Tym samym, miejsce działań zostaje niejako z góry wyznaczone - chcąc odzyskać utracone ziemie, drużyna krasnoludów wraz z Gandalfem i Hobbitem wyrusza na wschód ${ }^{82}$ pokonać zło. Przestrzeń w fantasy nie występuje jako samodzielny konstrukcyjny element utworu. Bohaterowie są zmuszeni pokonywać na swojej drodze przeszkody, nie tylko wynikające $\mathrm{z}$ fabuły utwo$\mathrm{ru}$, ale także z naturalnego ukształtowania terenu. Aby dotrzeć do Samotnej Góry, nieopodal Długiego Jeziora w kraju spustoszonym przez Smauga, muszą pokonać Góry Mgliste, Wielką Rzekę Dzikich Krajów, czy Mroczną Puszczę.

W przeciwieństwie do przestrzeni w baśni - domyślnej i nieokreślonej przestrzeń w Hobbicie jest wyraźna i określona. Powieściowy świat zbudowany jest z niezwykłą precyzją, wręcz z perfekcyjną dbałością o szczegóły. Każda postać, każdy ważniejszy przedmiot mają swoją historię. Tekst objaśniają dokładnie mapy oraz drzewa genealogiczne ${ }^{83}$. Mapa towarzyszy bohaterom niemal przez cały czas ich wędrówki z Bag End pod Pagórkiem do odległej Samotnej Góry:

Baggins (...) Często sięgał po mapę Thorina i wpatrywał się w nią, rozmyślając nad runami i wskazówką, którą Elrond wyczytał z księżycowego pisma. I nie kto inny, lecz właśnie pan Baggins namówił krasnoludów, żeby zabrali się do niebezpiecznych poszukiwań tajemnych drzwi w zachodnim stoku Góry ${ }^{84}$.

\footnotetext{
${ }^{80}$ Zob. Yi-Fu Tuan, Przestrzeń i miejsce, s. 61-62.

81 Tamże, s. 125.

82 Zob. wypowiedź Thorina: "Zamierzaliśmy maszerować na wschód jak najszybciej, najostrożniej, aż nad Długie Jezioro", J.R.R. Tolkien, Hobbit, s. 26.

83 Zwraca na to uwagę także E. Korulska, w: Hobbit, czyli Wielka Przygoda z lektura, Kraków

${ }^{84}$ J.R.R. Tolkien, Hobbit, s. 212.
} 1998, s. 17. 
Rzeczywistość, w którą bez reszty zanurza się czytelnik, za sprawą swej logiki i niepowtarzalności sprawia, że czytający odnosi wrażenie osobistego uczestnictwa $\mathrm{w}$ przestrzeni literackiej i udziału w przygodach bohaterów. To właśnie droga ${ }^{85}$ wytyczona mapą przodków Thorina, wiodąca bohaterów na wschód, równolegle prowadzi czytelnika i „zmusza” do jej studiowania, jakby w obawie o los wędrowców. Droga jest także doskonałym pretekstem do pokazania zmian w bohaterach. Im dłużej wędrują, tym większą mają wiedzę, przechodzą wiele prób, bardziej się rozwijają. Z tego powodu Hobbita z pewnością można określić mianem powieści drogi. Podróżując przez przepastne tereny Śródziemia, wędrowcy odwiedzają wiele pięknych miejsc, jak chociażby dolinę elfów - Rivendell czy malowniczą posiadłość Beorna, lecz na ich szlaku przeważają krajobrazy ciemne, ponure i groźne, zwłaszcza w Mglistych Górach i Mrocznej Puszczy:

Na ścieżkę wchodziło się jak gdyby przez sklepioną bramę do ciemnego tunelu utworzonego przez gałęzie dwóch ogromnych drzew, które pochylały się ku sobie, a tak były stare, tak ciasno oplecione bluszczem i tak brodate od porostów, że zachowały ledwie kilka sczerniałych liści. Ścieżka, bardzo wąska, wiła się kręto wokół pnis ${ }^{86}$.

Chociaż literackie alternatywne światy rządzą się innymi prawami niż nasz, nie da się zaprzeczyć ważnej dydaktycznej, wychowawczej i terapeutycznej roli utworów, które są utrzymane w konwencji fantastycznej. Przestrzeń literacką w Hobbicie należy uznać za nośnik wartości. Mimo iż w czasie podróży bohaterowie zmagają się z przeciwnościami losu, napotykają przeszkody, nikczemne postaci czyhające na ich życie, pozyskują także życzliwych przyjaciół, u których mogą się schronić, zregenerować siły i uzupełnić zapasy żywności. Czas spędzony razem, wspólnota doświadczeń i przeżyć powodują, że pomiędzy bohaterami zawiązuje się prawdziwa przyjaźń. I chociaż wszyscy maszerowali wspólnie, najdłuższą drogę przebył Bilbo. Wędrówka, na którą się zdecydował, sprawiła, że dokonała się w nim mentalna przemiana. Baggins stał się pewniejszy siebie, odważny i odpowiedzialny. Przebyta droga zahartowała go, uszlachetniła i nauczyła prawdziwego życia. Przewidział to zresztą zarówno czarodziej Gandalf, jak i Dwalin. Tuż po wyruszeniu w drogę, kiedy Hobbit użalał się, że zapomniał kapelusza i chusteczki do nosa, krasnolud stwierdził:

${ }^{85}$ Droga, obok granicy i wieży - zdaniem badaczy - to jeden z podstawowych wyróżników ponowoczesności i główny topos przestrzenny w literaturze, w tym w fantasy. Jest to element o tyle ważny, że samo jej pojawienie się niejako wymusza początek jakiejś akcji - pusty trakt oczekuje, że ktoś nim będzie szedł, prędzej czy później na drodze ktoś się pojawi. Droga jest więc związana z porządkiem czasowym, a zarazem zorganizowana $w$ sposób linearny i ukierunkowany, gdyż zawsze prowadzi do jakiegoś miejsca (dokądś). Zob. np. J. Puzynina, O języku wartości, Polonistyka, 1996, 4, s. 196.

${ }_{86}$ Opis Mrocznej Puszczy, J.R.R. Tolkien, Hobbit, s. 147. 
Nie bądź taki dokładny (...) i nie przejmuj się drobiazgami. Nim dobrniemy do celu podróży, nauczysz się obywać bez chustki do nosa i bez wielu innych rzeczy. Jeżeli zaś chodzi o kapelusz, mam w kuferku zapasowy kaptur i płaszcz ${ }^{87}$.

Dla Tolkienowskich bohaterów wędrówka "tam i z powrotem” okazała się wielką lekcją życia. Niewątpliwie także dla czytelnika droga przez Śródziemie może stać się niepowtarzalną okazją do przeżycia wspólnej przygody z lekturą. Dzięki możliwości identyfikacji z pozytywnymi wzorcami bohaterów, młody czytelnik ma okazję przekonać się, że warto dążyć do celu i że dobro zawsze zwycięża zło. Uświadamia sobie także wartość domu, przyjaźni, solidarności i lojalności. Jednak, zdaniem Myrdzik, „samego przekazu wartości nie można ograniczyć tylko do ich uświadamiania, nazywania, poznawania, czyli werbalnego przyswajania wiedzy o nich" ${ }^{\prime 88}$. Aby kontakt czytelnika z lekturą przyniósł korzyści wychowawcze, potrzebny jest odpowiedni "trening aksjologiczny" ${ }^{89}$, dlatego szczególną rolę ma tu do spełnienia szkolny polonista.

W dokonanej przeze mnie analizie wybranych projektów metodycznych ${ }^{90}$ na temat Hobbita jako lektury obecnej w szkolnej edukacji literacko-kulturowej trudno dopatrzeć się jednak szczególnego eksponowania przez nauczycieli problemu aksjologicznego. Brak głębszej refleksji aksjologicznej potwierdzają również obserwacje poczynione przeze mnie wśród nauczycieli. Szkolni poloniści rzadko dostrzegają znaczenie przestrzeni literackiej jako narzędzia uwrażliwiania na wartości. A pomijanie tego aspektu, według mnie, jest dużym niedostatkiem wobec dzieła Tolkiena i można nabrać przekonania, że potencjał lektury jest zaprzepaszczany poprzez takie jej traktowanie. Uważam też, że nie należy bezkrytycznie przyjmować i wykorzystywać różnorodnych propozycji rozwiązań metodycznych, tym bardziej w kontekście pożądanego modelu bycia „refleksyjnym praktykiem" ${ }^{91}$, a nie bezrefleksyjnym rzemieślnikiem.

87 Tamże, s. 36.

88 B. Myrdzik, Trudne tematy, trudne rozmowy, s. 53.

${ }^{89}$ Zob. tamże.

${ }^{90}$ Zob. na przykład: R. Jarząbek, Scenariusz lekcji poświęconych omówieniu lektury Hobbit, czyli tam i z powrotem J.R.R. Tolkiena,

http:/ / www.interklasa.pl/portal/index/dokumenty/interklasa/hobbit.doc?page=info\&action=showdoc\&oid=240682; E. Korulska, Hobbit, czyli Wielka Przygoda z lektura; J. Piasta-Siechowicz, M. Iwasiewicz, Praca z lektura $i$ jej filmowa adaptacja wedtug OWD (Ocenianie w Dialogu). "Hobbit”, Język Polski w Szkole IV-VI, Zeszyty Kieleckie, 2016/2017, 3, s. 42-59; J. Piasta-Siechowicz, G. Miszczyk, Wyprawa z Hobbitem, Język Polski w Szkole IV-VI, 2003/2004, 2, s. 62-68; Scenariusz lekcji: Bilbo Baggins w ksiażce i Internecie,

http://www.scholaris.pl/zasob/64683?bid=0\&iid=\&query=Hobbit\&api=; A. Sobańska, Szkolne Śródziemie. Gra literacka, Biblioteka w Szkole, 2015, 10, s. 28-30.

${ }^{91}$ Zob. więcej: M. Taraszkiewicz, Jak uczyć lepiej? Czyli refleksyjny praktyk w działaniu, Warszawa 1999. 
Jak zatem można wyzwalać wrażliwość na rolę przestrzeni literackiej jako nośnika wartości w szkolnej edukacji polonistycznej? Dostrzegam co najmniej kilka strategii postępowania z lekturą Hobbita. Po pierwsze, możliwości wychowawcze daje zastosowanie metody stawiania przez uczniów pytań ${ }^{92}$ oraz twórczego rozwiązywania problemów, na przykład poprzez technikę drzewka decyzyjnego ${ }^{93}$ lub metaplanu ${ }^{94}$. Dzięki tak zorganizowanej pracy z lekturą, uczniowie mogą aktywnie odnieść się do wartości uobecnionych w tekście literackim.

Jako pierwsze proponuję odniesienie do symboliki przestrzeni domu hobbita, który dla bohatera stanowi niepodważalną wartość. Niespodziewani goście, pojawiający się na początku utworu w norce tytułowego bohatera, pozwalają zainicjować na lekcji języka polskiego rozmowę na temat gościnności i zasad właściwego zachowania, ale także stanowi to dobrą okazję do twórczej dyskusji wokół problemem: W jaki sposób postąpiłbyś (postąpiłabyś), będąc na miejscu Bagginsa, gdyby do Twojego domu nagle przybywali nieproszeni goście? Inną dyskusję może zainicjować dylemat: Nieproszeni goście - dobrodziejstwo (radość) czy udręka (problem) gospodarza?

Analiza funkcjonowania Bagginsa poza miejscem zamieszkania daje kolejne możliwości. Przestrzeń Śródziemia uosabia spotkanie z niewiadomym, jest synonimem niebezpieczeństwa czyhającego w każdej chwili na bohaterów, ale także zaproszeniem do przeżycia przygody i poznania nieznanego świata. Atak goblinów i wilków, groźba utraty życia w pajęczej sieci, czy spotkanie w mrocznym lochu z Gollumem - to jedynie wybrane momenty w życiu powieściowych postaci, dzięki którym nauczyciel może zastosować "trening aksjologiczny". Niewątpliwie problemem zasługującym na refleksję jest zachowanie Bilba wobec czyhającego na jego życie Golluma ${ }^{95}$. Warto, moim zdaniem, zadać pytania: Czy bohater słusznie postąpił uciekając i nie zabija-

${ }_{92}$ Na temat roli pytań w dialogi z tekstem literackim pisze B. Myrdzik w: Rola hermeneutyki w edukacji polonistycznej, Lublin 1999.

${ }^{93}$ Metoda drzewka decyzyjnego pozwala graficznie zapisać proces podejmowania decyzji. Dzięki jej zastosowaniu znajduje się różne rozwiązania danego problemu i zauważa związki między tymi rozwiązaniami. Pozwala to również dostrzec skutki przyjętego rozwiązania. Bardzo istotne jest określenie wartości, jakie uznaje osoba, która podejmuje decyzję. Etapy postępowania $\mathrm{w}$ trakcie lekcji prowadzonej tą metodą są następujące: określenie problemu, określenie celów i wartości, podanie kilku rozwiązań (lub jednego), określenie pozytywnych skutków każdego rozwiązania, określenie negatywnych skutków każdego rozwiązania, podjęcie właściwej decyzji.

${ }^{94}$ Metaplan jest jedną z form prowadzenia dyskusji, zwaną też „cichą dyskusją”. W czasie narady (dyskusji) jej uczestnicy tworzą plakat, który jest graficznym skrótem dyskusji skoncentrowanej wokół problemu, odpowiadając na pytania: Jak jest? Jak powinno być? Dlaczego nie jest tak, jak być powinno? Następnie wyciągają wnioski prowadzące do rozstrzygnięcia omawianej kwestii.

${ }^{95}$ Zob. J.R.R. Tolkien, Hobbit, s. 93. 
jąc Golluma? Na czym, Twoim zdaniem, polega prawdziwa odwaga? Warto pozwolić uczniom wypowiedzieć się na temat motywów postępowania, etyki hobbita, ale także dowiedzieć się, w jaki sposób współczesny młody człowiek zachowałby się $\mathrm{w}$ podobnej sytuacji. Nie można pominąć też pytania o cel i sens wędrówki, zapytać: Co motywowało bohaterów wyruszających na wschód? Jaką lekcję wynieśli z podróży „tam i z powrotem”?

Tytułem podsumowania powyższych refleksji niech będzie - oczywista, wydaje się - konkluzja. Ukazanie funkcjonowania bohaterów Hobbita w dwóch kontrastujących ze sobą przestrzeniach - zamkniętej przestrzeni domu i otwartej przestrzeni Śródziemia - z całą pewnością uświadomi młodemu czytelnikowi, że w życiu takie wartości jak dom, poczucie bezpieczeństwa, rodzina, przyjaciele, sąsiedzi, doceniamy dopiero wówczas, gdy je utracimy. Często też nie dostrzegamy w życiu tego, co jest najważniejsze. Nie potrafimy wytyczyć sobie celu, do którego warto dążyć, bądź nie podejmujemy próby odnalezienia sensu życia. Warto zatem na te kwestie skierować uwagę młodego czytelnika, gdyż - mówiąc słowami Tolkienowskiego narratora - „Jeśli się chce coś znaleźć, trzeba po prostu szukać" ${ }^{\prime 6}$. I nie należy się zrażać faktem, iż „kto szuka, ten najczęściej coś znajdzie, niestety czasem zgoła nie to, czego mu potrzeba" ${ }^{97}$.

\section{BIBLIOGRAFIA}

Bachtin M., Formy czasu i przestrzeni w powieści, [w:] Problemy literatury i estetyki, red. M. Bachtin, Czytelnik, Warszawa 1982.

Bilbo Baggins w ksiażce i Internecie, http:/ / www.scholaris.pl/zasob/64683?bid=0\&iid=\&query $=$ Hobbit\&api $=$

Buczyńska-Garewicz H., Miejsca, strony, okolice. Przyczynek do fenomenologii przestrzeni, Wydawnictwo Universitas, Kraków 2006.

Czermińska M., Miejsca autobiograficzne. Propozycja w ramach geopoetyki, Teksty Drugie, 2011, 5(131).

Dereniowska M., Wokót przestrzeni natury: substytuty kulturowe jako narzędzie tworzenia przestrzeni życiowej człowieka, Inter Linie. Interdyscyplinarne Czasopismo Internetowe, 2011, 1, http://dspace.uni.lodz.pl:8080/xmlui/bitstream/handle/11089/6100/ 12-mazurkiewicz.pdf?sequence=1, [dostęp: 22.06.2017].

Doświadczenie lektury. Między krytyką literacką a dydaktyka literatury, red. A. Janus-Sitarz, Wydawnictwo Universitas, Kraków 2012.

Dylak S., Architektura wiedzy w szkole, Wydawnictwo Difin, Warszawa 2013.

Fantasy, [w:] Stownik literatury popularnej, red. T. Żabski, Wydawnictwo Towarzystwo Przyjaciół Polonistyki Wrocławskiej, Wrocław 1997.

Fantasy. Ilustrowany przewodnik, red. A. Miszkurka, Wydawnictwo Arkady, Warszawa 2003.

\footnotetext{
96 Tamże, s. 63.

97 Tamże, s. 64.
} 
Głowiński M., Przestrzenne tematy i wariacje, [w:] Przestrzeń i literatura, red. M. Głowiński, A. Okopień-Sławińska, Ossolineum, Wrocław 1978.

Głowiński M., Okopień-Sławińska A., Sławiński J., Zarys teorii literatury, WSiP, Warszawa 1975.

Has-Tokarz A., Czytelnictwo wspótczesnych nastolatków (opinie, obserwacje, badania), [w:] Kultura popularna w szkole. Pobłażliwe przyzwolenie czy autentyczny dialog, red. B. Myrdzik, M. Latoch-Zielińska, Wydawnictwo UMCS, Lublin 2006.

http:/ / www.interklasa.pl/portal/index/dokumenty/interklasa/hobbit.doc?page=info\&action $=$ showdoc\&oid $=240682$

http:/ / www.scholaris.pl/zasob/64683?bid=0\&iid=\&query=Hobbit\&api=

Jałowiecki B., Szczepański M., Miasto i przestrzeń w perspektywie socjologicznej, Wydawnictwo Naukowe Scholar, Warszawa 2002.

Jarząbek R., Scenariusz lekcji poświęconych omówieniu lektury Hobbit, czyli tam i z powrotem J.R.R. Tolkiena, Warszawa 202.

Kasperski E., W świecie potrzeb ludzkich, Przegląd Humanistyczny, 1979, 11-12.

Korulska E., Hobbit, czyli Wielka Przygoda z lektura, Wydawnictwo Edukacyjne, Kraków 1998.

Kulawik A., Poetyka. Wstęp do teorii dzieła literackiego, PWN, Warszawa 1990.

Kwiatkowska-Ratajczak M., Z perspektywy wartości o prozie dla dzieci i młodzieży, Wydawnictwo Nakom, Poznań 1994.

Leksykon polskiej literatury fantastycznonaukowej, red. A. Niewiadomski, A. Smuszkiewicz, Wydawnictwo Poznańskie, Poznań 1990.

Leszczyński G., Bunt czytelników. Proza inicjacyjna netgeneracji, Wydawnictwo Stowarzyszenie Bibliotekarzy Polskich, Warszawa 2010.

Literatura w kręgu wartości, red. S. Sawicki, Wydawnictwo KUL, Lublin 2009.

Mariański J., Sens życia - wartości - religia, Wydawnictwo KUL, Lublin 2013.

Markiewicz H., Czas i przestrzeń w dziele literackim, [w:] Wymiary dzieła literackiego, Wydawnictwo Literackie, Kraków 1984.

Mazurkiewicz A., Przestrzeń jako obraz świadomości w powieści Stanisława Lema "Pamiętnik znaleziony w wannie", Acta Universitatis Lodziensis. Folia Litteraria Polonica, 2013, $4(22)$.

Melosik Z., Kultura popularna jako czynnik socjalizacji, [w:] Pedagogika, red. Z. Kwieciński, B. Śliwerski, Wydawnictwo Naukowe PWN, Warszawa 2004.

Misiewicz J., Światopogląd i forma. O artystycznych wartościach literatury, Wydawnictwo Lubelskie, Lublin 1983.

Myrdzik B. Rola hermeneutyki w edukacji polonistycznej, Wydawnictwo UMCS, Lublin 1999.

Myrdzik B., Nauczyciel jako organizator dialogu ucznia z tradycja, [w:] Nowoczesność i tradycja w kształceniu literackim. Podręcznik do ćwiczeń z metodyki języka polskiego, red. B. Myrdzik, Wydawnictwo UMCS, Lublin 2000.

Myrdzik B., Trudne tematy, trudne rozmowy na lekcjach języka polskiego w gimnazjum, Język Polski w Szkole - gimnazjum, 2000/2001, 2.

Myrdzik B., Zrozumieć siebie i świat, Wydawnictwo UMCS, Lublin 2006.

Myrdzik B., Co ma wspólnego przestrzeń z edukacją polonistyczną?, [w:] Przestrzenie rzeczywiste i wyobrażone. Metodyczny wielogłos o różnych przestrzeniach, red. M. Latoch-Zielińska, I. Morawska, B. Myrdzik, Wydawnictwo UMCS, Lublin 2016.

Nalaskowski A., Przestrzenie i miejsca szkoty, Oficyna Wydawnicza Impuls, Kraków 2002.

Niewiadomski A., Mapa. Prolegomena, Brama Grodzka - Teatr NN, Lublin 2012.

Ogrodzka-Mazur E., Kompetencja aksjologiczna dzieci w młodszym wieku szkolnym, Wydawnictwo Uniwersytetu Śląskiego, Katowice 2007. 
Okoń W., Wprowadzenie do dydaktyki ogólnej, Wydawnictwo Akademickie Żak, Warszawa 2003.

Olbrycht K., Prawda, dobro i piękno w wychowaniu człowieka jako osoby, Wydawnictwo Uniwersytetu Śląskiego, Katowice 2002.

Piasta-Siechowicz J., Miszczyk G., Wyprawa z Hobbitem, Język Polski w Szkole IV-VI, 2003/2004, 2.

Piasta-Siechowicz J., Iwasiewicz M., Praca z lektura i jej filmowa adaptacją wedtug OWD (Ocenianie w Dialogu). „Hobbit”, Język Polski w Szkole IV-VI. Zeszyty Kieleckie, 2016/2017, 3.

Podstawa programowa z komentarzami. Język Polski, t. 2, MEN, Warszawa 2009.

Porębski M., O wielości przestrzeni, [w:] Przestrzeń i literatura, red. M. Głowiński, A. Okopień-Sławińska, Ossolineum, Wrocław 1978.

Przestrzenie rzeczywiste i wyobrażone. Metodyczny wielogłos o różnych przestrzeniach, red. B. Myrdzik, I. Morawska, M. Latoch-Zielińska, Wydawnictwo UMCS, Lublin 2016.

Przestrzeń edukacyjna wobec wyzwań i oczekiwań społecznych, red. I. Surina, Oficyna Wydawnicza Impuls, Kraków 2012.

Przestrzeń i literatura. Tom poświęcony VIII kongresowi slawistów red. M. Głowiński, A. Okopień-Sławińska, Ossolineum, Wrocław 1978.

Puzynina J., O języku wartości, Polonistyka, 1996, 4.

Raport z badań: Czytelnictwo dzieci i młodzieży, red. Z. Zasacka, Instytut Badań Edukacji, Warszawa 2014, http://eduentuzjasci.pl/images/stories/publikacje/ibe-raport-badanie-czytelnictwo-streszczenie.pdf [dostęp: 3.05.2017].

Raport z badań: Stan czytelnictwa w Polsce w 2015 roku, Biblioteka Narodowa, http:/ / www. bn.org.pl/download/document/1459845698.pdf [dostęp: 3.05.2017].

Rudzka A., Czas w fantasy, http://www.fahrenheit.net.pl/archiwum/fif_p1/36.html [dostęp: 23.05.2017].

Rybicka E., Od poetyki przestrzeni do polityki miejsca. Zwrot topograficzny w badaniach literackich, Teksty Drugie, 2008, 4.

Rybicka E., Geopoetyka. Przestrzeń i miejsce we wspótczesnych teoriach i praktykach literackich, Wydawnictwo Universitas, Kraków 2014.

Sawicki S., Problematyka aksjologiczna w badaniach literackich, [w:] Problematyka aksjologiczna w nauce o literaturze. Studia, red. S. Sawicki, A. Tyszczyk, Wydawnictwo KUL, Lublin 1992.

Sławiński J., Przestrzeń w literaturze: elementarne rozróżnienia i wstępne oczywistości, [w:] Przestrzeń i literatura, red. M. Głowiński, A. Okopień-Sławińska, Ossolineum, Wrocław 1978.

Sławiński J., Literatura w szkole: dziś i jutro, [w:] Teksty i teksty, red. J. Sławiński, Wydawnictwo Universitas, Kraków 2000.

Słownik terminów literackich, red. J. Sławiński, Ossolineum, Wrocław 2010.

Smuszkiewicz A., Fantastyka w gimnazjum, [w:] Horyzonty polonistyki. Wkreqgu edukacji, języka i kultury, red. M. Karwatowska, M. Latoch-Zielińska, I. Morawska, Wydawnictwo UMCS, Lublin 2010.

Sobańska A., Szkolne Śródziemie. Gra literacka, Biblioteka w Szkole, 2015, 10.

Stetkiewicz L., Kulturowi wszystkożercy sięgaja po książkę. Czytelnictwo ludyczne jako forma uczestnictwa w kulturze, Wydawnictwo Naukowe Uniwersytetu Mikołaja Kopernika, Toruń 2011.

Szpytma C., Rola architektury w tworzeniu aktywnego środowiska edukacji, Teraźniejszość Człowiek - Edukacja, 2016, 19, 1(73).

Taraszkiewicz M., Jak uczyć lepiej? czyli refleksyjny praktyk w działaniu, Wydawnictwa CODN, Warszawa 1999. 
Tolkien J.R.R., Hobbit, czyli tam i z powrotem, przekł. M. Skibniewska, Wydawnictwo Iskry, Warszawa 1997.

Tomkowski J., Bestsellery i arcydzieła, [w:] Zamieszkać w Bibliotece, red. J. Tomkowski, Wydawnictwo Dom na Wsi, Ossa 2004.

Tuan Yi-Fu, Czas w przestrzeni doświadczalnej, [w:] Yi-Fu Tuan, Przestrzeń i miejsce, przekł. A. Morawińska, PIW, Warszawa 1987.

Tuan Yi-Fu, Przestrzeń i miejsce, przekł. A. Morawińska, PIW, Warszawa 1987.

Tyszczyk A., Interpretacja, sens $i$ wartość, [w:] Wartość $i$ sens. Aksjologiczne aspekty teorii interpretacji, red. S. Sawicki, Wydawnictwo KUL, Lublin 2003.

Wartościowanie a edukacja polonistyczna, red. A. Janus-Sitarz, Wydawnictwo Universitas, Kraków 2008.

Włodarczyk J., Architektura szkoty, Wydawnictwo Arkady, Warszawa 1992.

Wójcicka E., Problemy współczesnych nastolatków w powieściach Marty Fox "Iza Anoreczka" i „Iza Buntowniczka”, Język Polski w Liceum. Zeszyty Kieleckie, 2015/2016, 1.

Wptyw doświadczenia na proces lektury czytelnika. Refleksje dydaktyczne, [w:] Przestrzenie rzeczywiste i wyobrażone. Metodyczny wielogłos o różnych przestrzeniach, red. M. Latoch-Zielińska, I. Morawska, B. Myrdzik, Wydawnictwo UMCS, Lublin 2016.

Zasacka Z., Nastolatki i ksiązki - od czytania codziennego do unikania, Edukacja, 2012, 2.

Zawada I., Przestrzeń edukacyjna klasy szkolnej, Roczniki Pedagogiczne, 2013, 5, 2. 